This item was submitted to Loughborough's Research Repository by the author.

Items in Figshare are protected by copyright, with all rights reserved, unless otherwise indicated.

\title{
VGC 2016: second virtual geoscience conference
}

PLEASE CITE THE PUBLISHED VERSION

http://dx.doi.org/10.1111/phor.12171

\section{PUBLISHER}

(c) The Remote Sensing and Photogrammetry Society and John Wiley \& Sons Ltd.

\section{VERSION}

AM (Accepted Manuscript)

\section{PUBLISHER STATEMENT}

This work is made available according to the conditions of the Creative Commons Attribution-NonCommercialNoDerivatives 4.0 International (CC BY-NC-ND 4.0) licence. Full details of this licence are available at: https://creativecommons.org/licenses/by-nc-nd/4.0/

\section{LICENCE}

CC BY-NC-ND 4.0

\section{REPOSITORY RECORD}

Chandler, Jim H.. 2019. "VGC 2016: Second Virtual Geoscience Conference”. figshare.

https://hdl.handle.net/2134/22703. 


\section{Conference Report}

\section{VGC 2016: SECOND VIRTUAL GEOSCIENCE CONFERENCE}

The 2ND Virtual Geoscience Conference (VGC 2016) was held between 21-23 September 2016 in Bergen Norway, following the successful "Vertical Geology Conference" held in Lausanne in February 2014. The title was modified slightly to reflect the revolution that is occurring in the geosciences, arising from the widespread adoption of close-range remote-sensing methods, and championed by The Photogrammetric Record for many years. As we recognise, the introduction of easy-to-use terrestrial laser scanning (TLS) and now structure-from-motion (SfM) photogrammetry has allowed anyone to use close-range spatial measurement to generate point clouds and detailed spatial representations of our surroundings. This has to be welcome, particularly if these new users are willing to learn from the photogrammetric expertise developed and expounded in the Record over the past 53 years.

The Bergen conference brought together an interesting mix of: geologists, volcanologists, geomorphologists (glacial/periglacial/coastal/landslide), computer scientists involved in virtual reality and a few photogrammetrists too. The final programme involved two keynote, 41 oral and 55 poster presentations, all supported by a technical exhibition (Fig, 1). Although the main event occupied two days it was preceded by three one day workshops, including one on Cloud Compare delivered by its creator. This was timely, as this freely available software has become the standard package to manipulate dense XYZ datasets, and in a way that Daniel Girardeau-Montaut only began to recognise in Bergen.
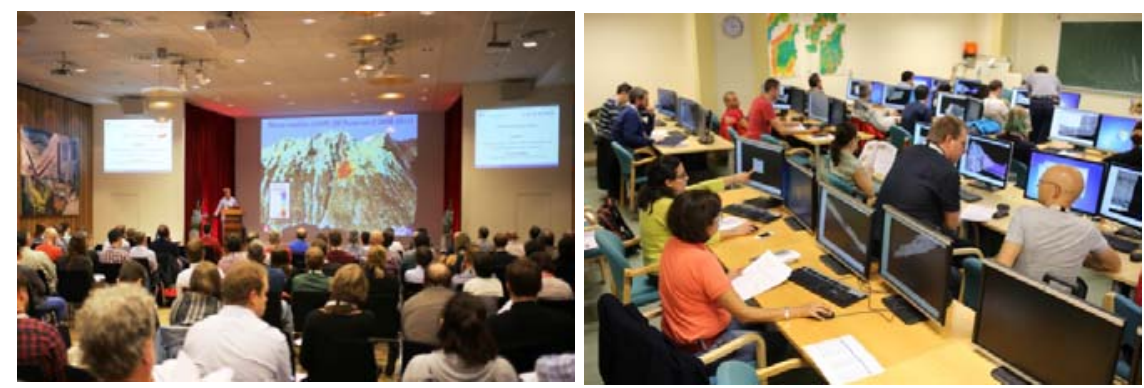

Fig. 1. Left: Lars Harald Blikra at a keynote session. Right: One of the pre-conference workshops.

The event was held in a small conference facility attached to the Hotel Terminus located in central Bergen (Fig. 2). The facilities were exceptional, being perfectly suited 
to the programme attended by 144 delegates from 20 countries. Each day followed a similar format with a keynote presentation, followed by a plenary and a parallel session before lunch. This was followed by a second plenary and poster and interactive sessions (Fig. 2) on the first day, replaced by a panel discussion on the final afternoon. Tea, coffee, snacks and fruit were freely available throughout and included a hot "Norwegian" buffet lunch. This was provided within the very reasonable delegate fee, which is notable in a country where food is expensive and the cost of living is high. Presentations were of a very high standard and delegates generated many fruitful discussions in all sessions. Two particular presentations were memorable to this reviewer. Nick Rosser (Durham University, UK) described ongoing monitoring work of the East Cliffs in Whitby, UK. Here a permanently operating TLS is capturing scans every 20 minutes and is beginning to show the importance of considering both spatial and temporal frequency of sampling. In addition, Andreas Kääb (University of Oslo) demonstrated the power of SfM photogrammetry to solve the mystery of a key process that has baffled scientists for generations - sorted stone circles found in periglacial regions. He acquired single-lens reflex (SLR) imagery of 3 such circles in 2007, 20102015 using a simple step ladder/pole. By using SfM photogrammetry and resolving very difficult datum challenges, the team was able to detect both morphological change and surface movement, which has proved that a super slow convection cell has been the cause of such distinctive features.
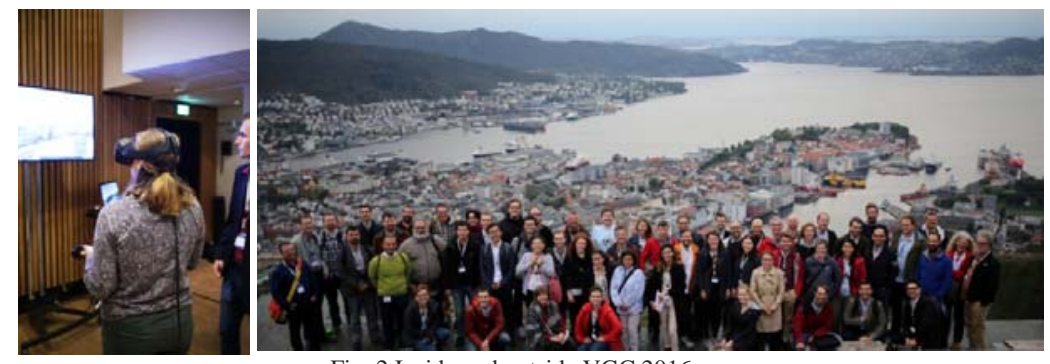

Fig. 2 Inside and outside VGC 2016.

The whole VGC 2016 conference was undoubtedly a major success and thanks must be given to Simon Buckley (our own IEB Coordinator) and his local team (Nicole Naumann, Tobias Kurz and Christian Eide) for their considerable efforts and attention to detail. As a scientific community we appear to have been seduced and drawn towards "mega conference" events, no doubt caused by the need to appear impactful and productive to our paymasters. Such mega events are increasingly expensive, political and not always effective in sharing knowledge through the generation of good honest debate and openness. This smaller and more intimate conference was very reminiscent of the

| very productive "Thompson Symposiaums" held by the former Photogrammetric Society. I would urge anyone interested in this rapidly developing field of application to look out for VGC 2018, location to be decided. 
Loughborough

University[s1] 